\title{
THE IMPACT OF SUPPLY CHAIN INTEGRATION ON FIRMS' BUSINESS AND OPERATIONAL PERFORMANCE AT THE FOOD RETAIL SECTOR/INDUSTRY
}

\author{
DOI: 10.17261/Pressacademia.2018.804 \\ JMML- V.5-ISS.1-2018(2)-p.18-30
}

\author{
Martin Boakye Osei ${ }^{1}$, Celal Hakan Kagnicioglu ${ }^{2}$ \\ ${ }^{1}$ Anadolu University, Eskisehir, Turkey. \\ boakye.martin8687@yahoo.com, ORCID: 0000-0002-8375-2309 \\ ${ }^{2}$ Anadolu University, Eskisehir, Turkey. \\ chkagnic@anadolu.edu.tr, ORCID: 0000-0001-7164-3538
}

To cite this document

Osei, M.B, Kagniciogu, C.H. (2018). The impact of supply chain integration on firms' business and operational performance at the food retail sector/industry. Journal of Management, Marketing and Logistics (JMML), V.5(1), p.18-30.

Permemant link to this document: $\underline{\text { http://doi.org/10.17261/Pressacademia.2018.804 }}$

Copyright: Published by Press Academia and limited licenced re-use rights only.

\begin{abstract}
Purpose-This study researched into the impact of supply chain integration and firm performance of food retailers in Turkey. The main purpose of this study was to identify the impact of internal and external supply chain integration on firms' business and operational performance in the food retail sector in Turkey.

Methodology-Two big cities in Turkey, namely, Istanbul and Eskişehir were selected for this study due to the availability of major food retailers in these cities. Stratified sampling method was used to select respondents. In total, 216 firms were selected out of which only 208 firms responded to the questionnaire distributed. Structural Equation Model specifically Amos was used to analyse the data.

Findings-The study found a positive and significant relationship between internal and external integration, and the study also found a significant and a positive relationship between internal integration and firms' operational and business performance. On the other hand, the study also found a significant and a positive relationship between external integration and firms' operational and business performance.

Conclusion- Consequently, retailers in Turkey were admonished to practice and uphold supply chain collaboration with their suppliers and customers.
\end{abstract}

Keywords: Supply chain management, supply chain integration, food retailers, operational performance and business performance JEL Codes: L81, M16, M11

\section{INTRODUCTION}

Essentially, supply chain management encompasses companies or business activities needed to design, make or deliver and use a product or service. Currently, supply chain management has been defined to include supply chain integration. Stank, Crum and Arango (1999) and Zailani and Rajagopal (2005) defines SCM as a network that includes vendors of raw materials, plants that transform those materials into useful products and distribution centres to get those products to customers. SCM also known as the value chain, is the sequence, which involves producing and delivering of a product or service. However, Supply Chain Management is not just another name for logistics. SCM is more comprehensive as it includes numerous systems and coordination of activities. The supply chain does not only include the manufacturer and suppliers, but also transporters, warehouses, retailers and customers themselves (Chopra and Mendl, 2001). The above definitions of Supply Chain Management clearly stipulate that SCM involves the effective coordination of all functions and members in the supply chain management. This coordination is what is termed as integration.

Stank, Crum and Arango (1999) and Zailani and Rajagopal (2005) defines SCM as a network that includes vendors of raw materials, plants that transform those materials into useful products and distribution centres to get those products to customers. SCM also known as the value chain, is the sequence, which involves producing and delivering of a product or service. SCM is more comprehensive as it includes numerous systems and coordination of activities. The supply chain does 
not only include the manufacturer and suppliers, but also transporters, warehouses, retailers and customers themselves (Chopra and Mendl, 2001). The above definitions of Supply Chain Management clearly demonstrate that SCM involves the effective coordination of all functions and members in the supply chain management. This coordination is what is termed as integration. Integration essentially involves all the parties in a supply chain coordinating and each playing the needed role to ensure the efficiency and effectiveness of the supply chain. The ultimate tool and the prerequisite for effective integration is information integration. If all the parties involved in a supply chain can operate in a networked environment, where information flows unceasingly between the parties, supply chain integration would be overly effective.

The food retail in Turkey can be categorized into major groups; organized and unorganized retailers. The organized retailers consist of the multi-formats retailers, supermarkets, hypermarkets, discount retailers and gas station stores. On the other hand, the unorganized group of retailers includes; traditional markets, individual convenience stores and open-air bazaars. However, this current research classified retailers in Turkey into organized retailers mainly, supermarkets, hypermarket, wholesalers and all unorganized retailers into mini markets.

Gimenez and Ventura (2005) suggested that future research on SCl and firm performance should concentrate on grocery supply chain relationships. Evidently, this research is appropriate and highly essential to the literature of $\mathrm{SCl}$ and firm performance. Clearly this research aims at providing a sounding answer to some of the gaps in the supply chain literature.

Therefore, the main purpose of this study is to explore the impact of integration activities on firm's performance in the food retail industry in Turkey by mainly examining the relationship between internal and external integration and the impact these internal and external integration have on firm's operational and business performance in the industry. The independent variables in this study, are internal and external integration. On the other hand, the dependent variable in this study is firm performance. This research is to contribute to the existing literatures of supply chain integration and performance in three ways; to examine whether food retailers in Turkey practice integration, secondly, whether internal integration has actual effect on external integration and whether both external and internal integration have a positive relationship with firm performance. The findings and conclusion of this research is expected to aid in the decision-making process of retailers to make strategic decisions whether to strengthen or ignore integration activities. These decisions are highly essential since the outcome has a major influence on the performance of the firm. This research, to the best of my knowledge, would be the first to rigidly research into the impact of $\mathrm{SCl}$ on firm performance with retailers.

In the next section, several literatures and theories underpinning supply chain integration and firm performance are carefully reviewed. This will include the definition of the technical terms used in this study and subsequently, the hypotheses of the study would be discussed. The subsequent section would contain the methodology used in this study specifically, conceptual model, the data collection instrument, the population of the study and the analyses of the study and its accompanying interpretation. Finally, the last section would present the results of the study and eventually, the conclusion and the suggestions for future research.

\section{LITERATURE REVIEW}

This section of the study contains the review of several literatures and theories relating to the concept of supply chain integration and firm performance. Most of this section contains the empirical review of the findings of issues related to the fundamentals of supply chain integration and it further presents the findings of the impact of one dimension, thus, external integration on firm performance. Additionally, the empirical review would cover the findings of other literatures relating to the impact of the whole supply chain integration on firm performance.

Fundamentally, many theories and studies relating to the impact of supply chain integration on firm performance are based on the suggestions and theories provided by Stevens. Stevens (1989) provided the main basis for integrating supply chain. The research confirmed that, the effective balancing of the supply chain management involves the concurrent balancing of cost and service. Furthermore, the study confirmed that, for the impediments (obstacles) in the supply chain management to be annihilated, firms need to develop an integrated supply chain which is purposefully driven by the needs of the business. In the view of this study, integration requires the management of material flow and should be viewed from three perspectives, namely; strategic, tactical and operational. In a nutshell, this study confirmed the two types of integration which are mainly; external (supplier and customer) and internal which and suggested external integration can only be triggered if internal integration is solid.

With regards to the impact of external on firm performance; Stank, Crum and Arango (1999), researched into the benefits of interfirm coordination in Food Industry Supply chain. Externally, the research emphasized on communications, information exchange, partnering and performance monitoring as the factors that trigger a firm's source, make and deliver activities of suppliers and customers (El-Ansary, 1992). It was revealed that, interfirm coordination has a positive relationship with performance. Scannell, Vickery and Droge (2000) investigated how upstream supply chain management affect competitive performance of firms in the automotive supply industry in the United States of America. Despite supplier 
partnering having a positive relationship with flexibility and cost and negative relationship with innovation and quality, it was found that, supplier partnering is significantly related to competitive performance.

Zhao, Huo, Flynn and Yeung (2008) investigated the impact of power and relationship commitment on the integration between manufacturers and customers in a supply chain. The study examines holistically customer integration through the application of transaction cost theory and social exchange theory and simultaneously investigated the impact of power and relationship commitment on customer integration by using power-relationship commitment theory. The study confirmed that significant utilization of power in a firm can exert and improve relationship commitment which would further improve customer integration. Prajogo and Olhager (2012) investigated into the effects of supply chain integration on firm performance. The study examined specifically how long-term effects relationships, information technology and sharing and logistics integration have an impact on firm performance. Contrary to $\mathrm{SCl}$ literature, the most commonly used integration dimensions were three; internal, customer and supplier where both customer and supplier were classified as external integration. Performance in this study was measured by only operational performance variables and not financial performance. The study revealed that, both information and material flow are positively related to supply chain integration which implies that integration is significantly related performance and has a positive effect on performance.

Other studies also focused on the impact both internal and external integration have on firm performance. Stank, Keller and Daugherty (2001) is considered as one of the contemporary bedrock study on the impact of integration and firm performance. The study researched into the impact of the whole dimensions of supply chain collaboration on logistical service performance (firm performance). Impliedly, this research sought to investigate the whole impact of both internal and external integration on logistical service performance (firm performance). The study discovered that internal integration significantly influences logistical service performance. However, contrary to other studies, this research discovered that external integration has no influence on logistical service performance (firm performance). Similarly, Germain and lyer (2006) investigated the impact of internal and external integration on logistics performance and financial performance. The study also examined the moderating role that internal integration plays on the relationship between external integration and logistics performance. The research found that internal and external integration have a positive relationship with logistics performance (operational performance). Moreover, the internal integration was found to be highly moderating the relationship between external integration and logistical performance. However, both internal and external integration were found to have no positive relationship with financial performance but the relationship was mediated through logistical performance.

In order to confirm and criticize the findings of Stank et al., (2001), Gimenez and Ventura (2003) investigated the issue of supply chain management as a source of competitive advantage in the Spanish grocery sector. This research extensively criticized the findings and methodology used by Stank et al., (2001). The study discovered that internal integration is a precedent to external integration and both internal and external integration have a positive influence on performance, contrary to the findings of Stank et al., (2001). Flynn, Huo and Zhao (2010) further contributed to the literature of SCI by investigating the impact of supply chain integration on performance, through the use of the contingency and configuration approach. The performance was categorized into business and operational. The business performance was represented by financial performance metrics which included Return on Assets (ROA), Return on Investment (ROI) and return on sales. After a careful analysis, the research suggested that $\mathrm{SCl}$ has a significant relationship with firm performance, although supplier integration was found to have an inverse relationship with performance, both supplier and customer integration together had a positive influence on performance.

Droge, Jayaram, and Vickery (2004) examined the effects of internal and external integration on time-based performance and overall firm performance in the automotive industry in the United States of America. To measure external integration, the study selected supplier partnerships, supplier development and closer customer relationships and internal integration was measured by concurrent engineering, design for manufacturability, standardization and computer-aided design/computer-aided manufacturing metrics. Performance in this study was categorized into both operational and financial performance. The study discovered that integration enhances product innovation (time-to-product) and product introduction (time-to-market) and these exert a positive influence on firm performance which is market share and financial performance.

Groves and Valsamakis (1998) also studied the impact supplier-customer relationship has on company performance (firm performance). The study investigated the different types of relationships firms engage in. Although, the study recognised the dominance partnerships (integration) as the dominating and beneficial relationship, two other different types of relationships between supplier and customers were found. The performance metrics used in this study were made up of only financial performance metrics rather than the holistic firm performance measuring metrics. Base on the findings, it was revealed that there is a potential for better performance for manufacturers who engage in closer relationship with 
suppliers and customers (external integration). However, the research identified various gaps in the integration process of firms and could not wholly adjudge the relationship which should be practiced most by firms.

Vickery, Jayaram, Droge and Calantone (2003) examined the effects of an integrative supply chain strategy on customer service and financial performance through an analysis of direct and indirect relationships. The result indicated a positive relationship between information technologies and supply chain integration which directly affects customer service and financial performance. However, only customer service and financial performance constructs (ROA, ROI, market shares, stock prices) were used to measure the firm performance. Vargas, Cardenas and Mataranz (2008) further researched into the internal and external integration of assembly manufacturing activities in the Spanish manufacturing industry. The research focused on analysing the various integration choices by manufacturing firms in the Spanish Economy. The study revealed that integration programs have no relationship with quality. Furthermore, the research discovered that firms still place greater importance on internal integration than external integration for the achievement of their strategic goals and priorities and finally, both dimensions of integration had a positive influence on competitiveness and profitability.

It can be concluded the previous researchers used different metrics and variables to measure performance and supply chain integration. Nonetheless, most of the research although were conducted in different countries and industries yielded similar results with few of them obtaining results to the contrary.

\section{DATA AND METHODOLOGY}

This section describes the method, data collection procedure, the instrument and the tools used in analyzing the data used in conducting this research. The next section describes the conceptual model from the literature of this study, the subsequent sections would describe the tools used in collecting data, data collection techniques and the analysis of the data.

\subsection{Hypothesis}

From the literature reviewed above, the research hypothesizes that;

$\mathrm{H}_{1}$ : Internal Integration has a positive relationship with External Integration.

$\mathrm{H}_{2}$ : Internal Integration has a positive relationship with Firm Performance.

$\mathrm{H}_{3}$ : External Integration has a positive relationship with Firm Performance.

Figure 1: Conceptual Model

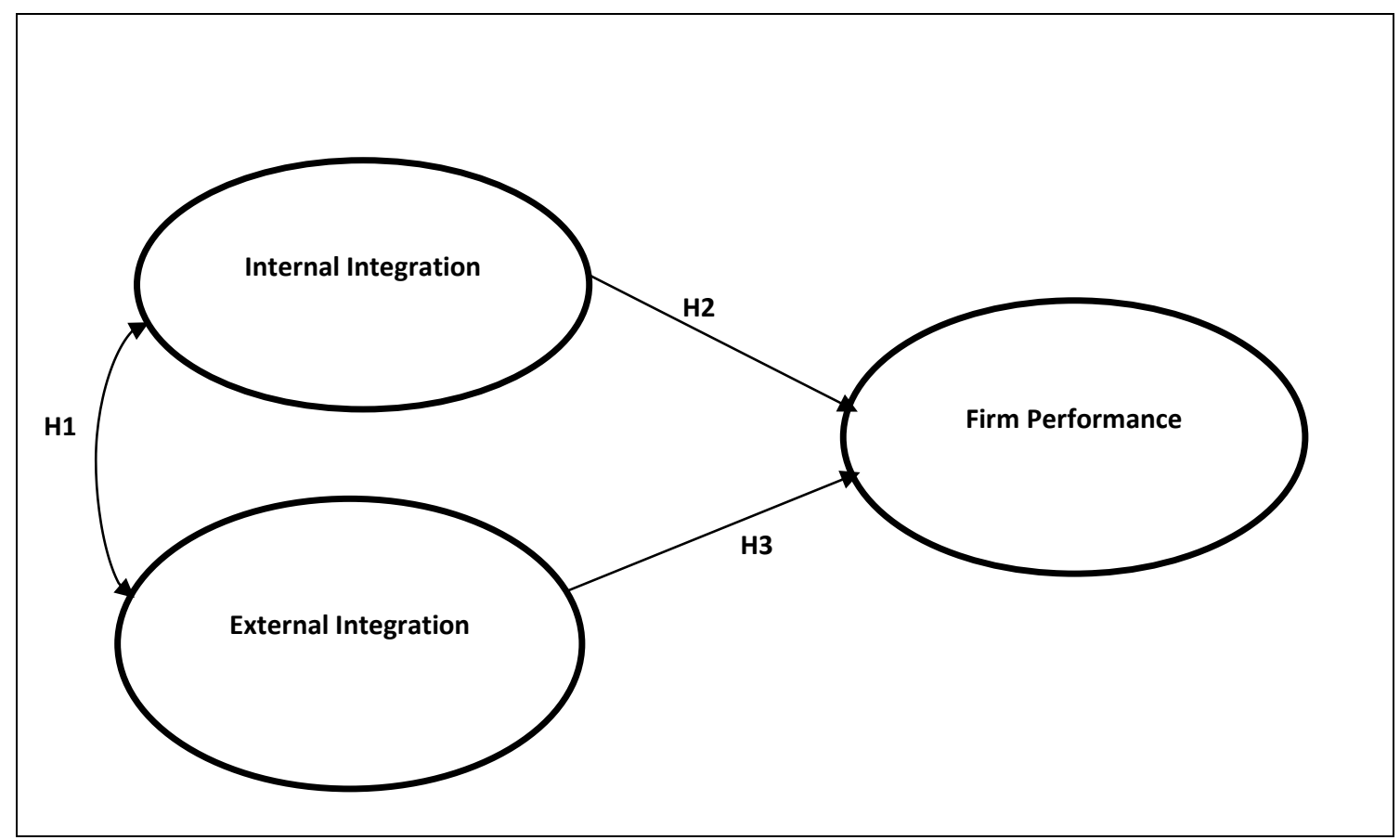


The figure above represents the conceptual model fully illustrating the hypothes Es of the study. In $\mathrm{H} 1$, it is hypothesized that internal integration will have a positive relationship with external integration. Similarly, in $\mathrm{H} 2$, it is hypothesized that Internal integration will have a positive relationship with firm performance and lastly, H3 stipulates that the external integration of firms will have a positive relationship with firm performance. The oval shaped figures demonstrated in the model was chosen to represent the latent variables in the study. In Structural Equation Modelling (SEM), the unobserved variables are represented in oval shapes and the manifested or observed variables are represented in rectangles. Since the variables in this current study are unobserved variables, it is worthwhile they are represented in oval shapes.

\subsection{Development of Data Collection Instrument}

The questionnaire designed purposefully for this study was adopted from the survey instrument developed by (Stank, Keller \& Daugherty, 2001). The instrument was developed from the survey instrument designed by the World Class Logistics Research at Michigan State University. This current study also conducted a pilot study with small retailers in order to broaden the measures for all the variables used in the study. Furthermore, the performance measures were widened by adding more metrics to measure the financial aspect of firms' performance since one of the aims of this study was to measure the business (financial) and operational performance of the firms. Therefore, a questionnaire with four parts/departments was developed.

The first part of the questionnaire focused on the demographic information of the respondents. Firms were asked to respond to four questions which basically solicits information about the firms. Firms were asked if they had a supply chain manager. The main aim of this question was to investigate whether firms were practicing supply chain activities since the presence of a supply chain manager would signify the presence of supply chain practices in the firms. Secondly, to substantially cover the definition provided by the Small and Medium Scale Enterprises Association in Turkey, firms were also asked to select their annual sales from four options; i. 0-1,000,000 ii. 1,000,000-8,000,000 iii. 8,000,000-40,000,000 and iv. 40,000,000 and above with all the amount denominated in Turkish currency, Turkish Lira (TL). Respondents were also asked to state their positions or title in the firm. This question was inserted and targeted at generating the authenticity of the research and the response from supply chain managers or someone at the upper management would indicate the genuineness of the information. Lastly, respondents were provided with four options which is made up of the various category of retailers defined in this study. Specifically, respondents were asked to state whether their firm was a supermarket, hypermarket, mini market or a wholesale firm.

The second part of the questionnaire measured the internal integration of the firm. Eight (8) metrics were selected to represent internal integration of the firm. Table 1 below clearly illustrates the eight (8) metrics used in measuring the internal integration practices of the firms. Firms were asked to measure their internal integration activities on a five-point Likert scale where $1=$ strongly disagree, $2=$ disagree, $3=$ =neutral, $4=$ agree and $5=$ =strong agree.

The third section of the questionnaire measured external integration. Firms were asked to respond to nine (9) items representing external integration activities that the firms were likely to practice. The items are clearly listed in Table 1 below. Similarly, firms were asked to measure their internal integration activities on a five-point Likert scale where $1=$ strongly disagree, $2=$ disagree, $3=$ neutral, $4=$ agree and $5=$ strong agree. The design of the questionnaire is illustrated by Appendix 1.

Since the official language in Turkey is Turkish, the survey instrument was officially translated from English to Turkish language by linguistic experts and was assessed by faculty members and research assistants at Anadolu University whether the translated instrument had the exact meaning as the English version of the questionnaire. The Turkish version was again translated back into English by another linguistic expert and the English version was checked on sentence by sentence basis to check against the original English Version. Furthermore, this process was conducted to check the discrepancy level. After its clarity was ascertained, the Turkish version was then administered to respondents.

\subsection{Data Collection and Sampling}

The research targeted supermarkets, hypermarkets, mini markets and wholesale markets and it was conducted in Turkey specifically Istanbul and Eskisehir. Moreover, this study will concentrate on two cities in Turkey, namely, Eskişehir and Istanbul. These two cities were selected because of the availability, proximity and easy accessibility of the target population in this area. The total number of the population relevant to the study was approximately 8,545. The list of food retailers was obtained from the Chamber of Commerce in both cities. This number comprises the supermarkets, hypermarkets, mini markets and wholesalers in both Istanbul and Eskişehir in Turkey. However, the research adopted stratified random sampling technique where the following features were used in selecting the required retailers for the study; firms with food consisting of about half of the products offered for sale in store, firms with more than one internal department and more than two branches in more than one city in Turkey, and firms which have direct relationship with manufacturer (supplier) 
were selected for the study. With the firms in Eskişehir, those with more than two branches in other geographical areas in the city were selected for the study. After considering the characteristics, the study selected 216 firms from the population since these firms met all the criteria of the stratified sampling technique used. 216 firms fairly represent the major retailers in both cities selected for the study and Turkey. Categorically, 100 firms were selected from Eskisehir and 116 firms from Istanbul.

Given the strategic focus of the research and the distance of the respondents, the questionnaire was sent to the selected targeted population in both Eskisehir and Istanbul. The questionnaire was distributed to respondents in Eskişehir by hand because of the easy accessibility of the respondents. However, the same questionnaire in Turkish Language was further developed on google forms and despatched to the firms in Istanbul via electronic mail (e-mail). The selected firms were first contacted on the telephone to make them aware of such kind of research and to ask of the official e-mail address(es) of either the supply chain manager or the CEO. After the e-mail addresses were acquired, the questionnaire was despatched to the various firms. Follow-up e-mail and phone calls were made to the firms, however, after a certain period of not receiving a positive response from the respondents, data collection agents were employed to administer the questionnaire to the same firms in Istanbul.

\subsection{Basic Analyses}

Out of 216 questionnaires issued to the respondents. 208 were filled accurately and returned. This represents $96.30 \%$ response rate. out of 208 respondents, 132 responded Yes when asked whether there is a supply chain manager in the firm. On the other hand, 76 responded No to this question. 69 firms have annual sales of between 0-1.000.000TL, 49 of the firms have their annual sales between 1.000 .000 and $8.000 .000 T L, 41$ have annual sales between 8.000 .000 and $40.000 .000 T L$ and 49 of the firms have annual sales above 40.000 .000 TL. Moreover, in other to further ascertain the size of the firm as it is relevant to the results of this section, part of the questionnaire included questions where firms were asked about the number of employees in the firm. 95 of the firms have employees between the range of 0-9, 44 have employees between the range of 10-49, 27 have employees in the range of 50-249 and 42 of the firms have 250 and above employees. Also, 20 CEO's, 1 supply chain manager, 23 general managers, 2 marketing and customer relation managers, 4 general directors, 4 finance directors, 21 accountants, 11 sales directors, 42 branch managers, 35 cashiers, 1 strategic director, 3 information system managers, 17 secretaries, 12 owners, 6 employees and 6 shop assistants filled out the questionnaires. Furthermore, only 68 supermarkets, 18 hypermarkets, 95 mini markets and 27 wholesale enterprises participated in the study.

This study was a quantitative research and therefore, it was imperative that the measurement scales or the variables were subjected to validity and reliability tests. Principal and confirmatory factor analyses were conducted on the variables to ascertain their reliability and validity and precisely unidimensional characteristics for all the measurement scales/variables (Stank et al., 2001). To test the validity and reliability of the variables, Cronbach Alpha, principal component and factor analysis were used. Additionally, factor analysis was conducted to test the hypotheses and the model fit. Table 1 below summarizes Cronbach Alpha Test, principal component and factor scores.

Table 1: Principal Component, Confirmatory Factory Analysis And Cronbach Alpha

\begin{tabular}{|l|c|c|c|c|c|}
\hline ITEMS & PC SCORES & $\begin{array}{c}\text { FACTOR } \\
\text { SCORES }\end{array}$ & $\begin{array}{c}\text { ITEM-TO-TOTAL } \\
\text { CORRELATION }\end{array}$ & $\begin{array}{c}\text { ALPHA IF ITEM } \\
\text { IS DELETED }\end{array}$ & $\begin{array}{c}\text { CRONBACH ALPHA } \\
\text { FOR SCALE }\end{array}$ \\
\hline Internal & & & & & .908 \\
Integration & .636 & .681 & .693 & .897 & .901 \\
INT IG 1 & .563 & .617 & .654 & .894 & \\
INT IG 2 & .713 & .759 & .738 & .897 & \\
INT IG 3 & .604 & .689 & .690 & .899 & \\
INT IG 4 & .650 & .703 & .669 & .898 & \\
INT IG 5 & .660 & .710 & .674 & .891 & \\
INT IG 6 & .744 & .800 & .761 & .890 & \\
INT IG 7 & .759 & .824 & .766 & & \\
INT IG 8 & & & & .903 \\
\hline EXternal & & & .502 & \\
Integration & .607 & .595 & .740 & .889 & \\
EXT IG 1 & .718 & .745 & .716 & .892 & \\
EXT IG 2 & .680 & .717 & .679 & .891 & \\
EXT IG 3 & .679 & .715 & .713 & & \\
EXT IG 4 & .661 & .679 & .688 & & \\
EXT IG 5 & & & & & \\
\hline
\end{tabular}




\begin{tabular}{|c|c|c|c|c|c|}
\hline $\begin{array}{l}\text { EXT IG } 6 \\
\text { EXT IG } 7 \\
\text { EXT IG } 8 \\
\text { EXT IG } 9\end{array}$ & $\begin{array}{l}.729 \\
.666 \\
.729 \\
.653 \\
\end{array}$ & $\begin{array}{l}.735 \\
.700 \\
.770 \\
.659 \\
\end{array}$ & $\begin{array}{l}.680 \\
.702 \\
.754 \\
.612 \\
\end{array}$ & $\begin{array}{l}.891 \\
.890 \\
.886 \\
.897 \\
\end{array}$ & \\
\hline $\begin{array}{l}\text { Firm } \\
\text { Performance }\end{array}$ & & & & & .886 \\
\hline PERF 1 & .506 & .543 & .556 & .878 & \\
\hline PERF 2 & .599 & .622 & .629 & .874 & \\
\hline PERF 3 & .655 & .679 & .640 & .873 & \\
\hline PERF 4 & .534 & .600 & .642 & .874 & \\
\hline PERF 5 & .535 & .645 & .631 & .875 & \\
\hline PERF 6 & .578 & .692 & .671 & .872 & \\
\hline PERF 7 & .651 & .740 & .713 & .869 & \\
\hline PERF 8 & .586 & .669 & .573 & .877 & \\
\hline PERF 9 & .719 & .733 & .615 & .875 & \\
\hline PERF 10 & .523 & .658 & .658 & .872 & \\
\hline PERF 11 & .661 & .704 & .665 & .872 & \\
\hline
\end{tabular}

Statistically, all principal component and factor scores that meet or exceed .60 are normally considered as viable for further analysis. In Table 1 above, all the variables except few of them meet or exceed these criteria of validity. Moreover, internal consistency of the variables was tested using the Cronbach Alpha (Cronbach, 1951; Jayram and Tan, 2010). Statistically, Cronbach Alpha values exceeding 0.60 are considered highly reliable for analysis (Jayram and Tan, 2010). In Table 4.2 above, the Cronbach Alpha values for all the factors including the values if Alpha is deleted are outstanding as they are between the range of .80 and .90 .

\subsection{Empirical Results}

The main aim of this study was to explore the effect of supply chain integration on firm operational and business performance at the food retail sector. Also, since the independent variables were more than one, it was recommended that the data be analysed with a structural equation modelling software, specifically AMOS. This section contains the detailed analyses of the test of the hypothesis and the model fit.

In structural equation modelling, determining the fit of the model is a major determinant factor of the accuracy of the model and the gateway for accurate regression analysis (Stank et al.,2001). Although, some of the model fit indices indicate weak measures, they are however, eligible for further analysis. The Chi-square was significant based on the number of data available for analysis and because chi-squares are highly responsive to number of data. Chi-square $(897.99, d f=317, p=0.00)$. These results were obtained after series of adjustments were made to the model. The indices obtained after the adjustments were (GFI=.777; $\mathrm{CFI}=.846$; RMR=.097; RMSEA=.0052; NNFI=.783; PCLOSE=.000; IFI=.848; TLI=.816). The analysis would further be presented on the table below.

Table 2: Model Fit Indices

\begin{tabular}{|l|c|c|c|c|c|c|c|c|c|c|}
\hline $\mathbf{X}^{2}$ & DF & $\begin{array}{c}\text { P } \\
\text { VALUE }\end{array}$ & GFI & CFI & RMR & RMSEA & NNFI & PCLOSE & IFI & TLI \\
\hline 897.997 & 317 & .000 & .777 & .846 & .097 & .0052 & .783 & .000 & .848 & .816 \\
\hline
\end{tabular}

Table 2 above summarizes the model fit indices extracted from Amos. In Table 2 above, The Goodness of fit index (GFI), Comparative Fit Index (CFI) and others such as Incremental Fit Index (IFI) were conducted. The normal and recommended fit level is .90 but the values in-between zero and one are also considered. Statistically, RMSEA value of 0.05 or less is considered to indicate a good fit of the model (Arbuckle, 2005). However, Hu and Bentler (1999) recommend RMSEA of 0.06 or less to indicate a perfect fit. CFI and TFI values of .95 or higher are considered to indicate a perfect model fit. GFI should be approximately 1 or sometimes .95 is accepted for a good fit. Some of the indices, although, do not meet the standard criteria are still be eligible for further analysis. 


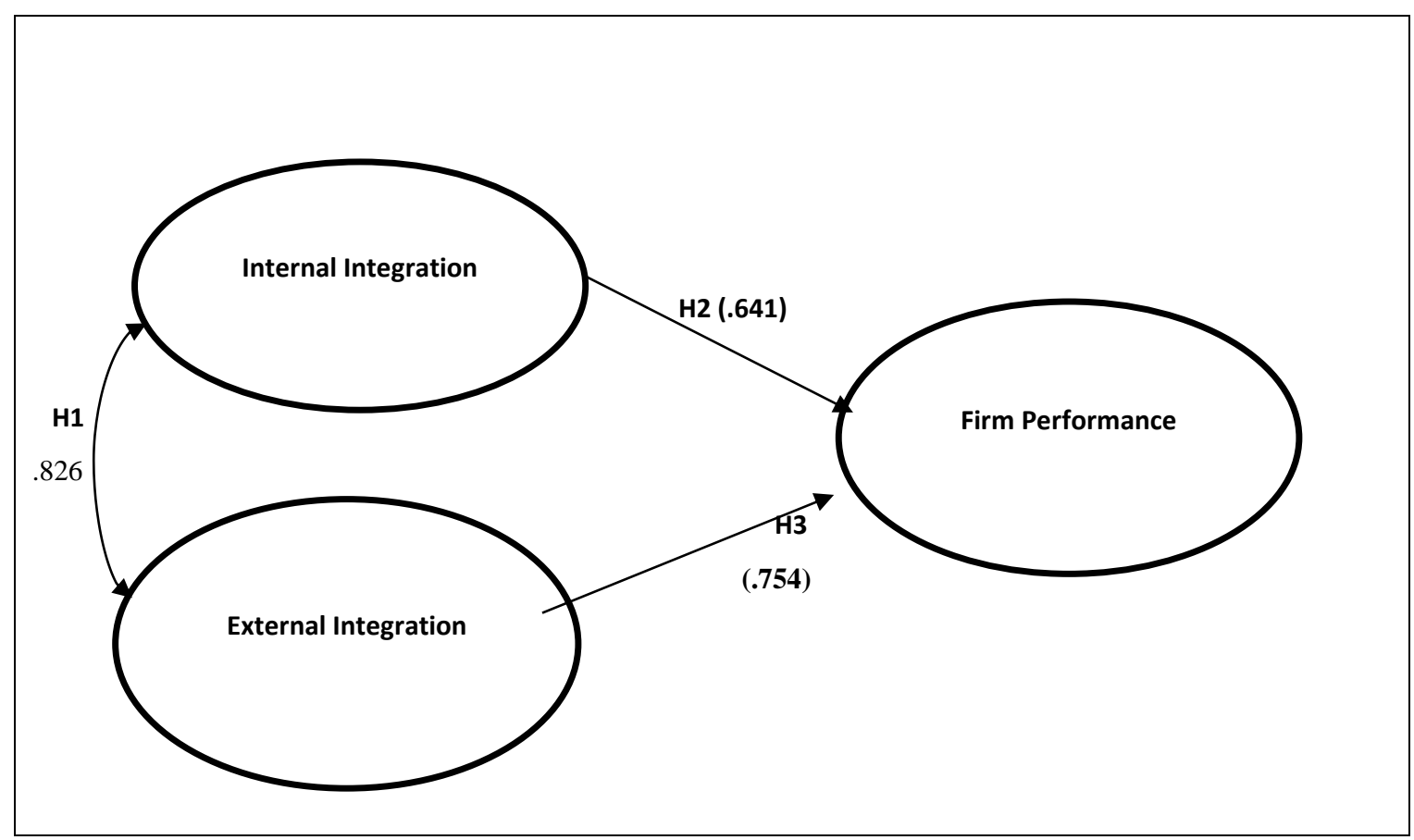

The figure above presents the results of the hypotheses testing. It summarises the correlation coefficient between the variables of the study. In figure 1 above, the correlation coefficient for each of the hypothesis is represented in a bracket. The significant values of each of the hypothesis is .00

0 . The correlation coefficients and their related significant values clearly pave way for the results of the analyses to be firmly discussed. The presumption that internal integration has a positive relationship with external integration implies that, the effective collaboration of the internal affairs of the food retailers has a positive relationship with their external partnership with their partners. The correlation coefficient of 0.826 clearly represents the highest correlation and the significant value of .000 indicates internal integration is highly and significantly related to external integration of food retailers and such relationship is positive. Hypothesis 1 is highly supported. This research posited that internal integration of food retailers has a positive relationship with firm performance; financial and operational performance. Meaning, the effective collaboration of internal activities of firms has a strong influence on the outcome of the firms' financial and operational activities. This was confirmed as the research found that effective inter and intra departmental communication, sharing of rewards and risk and other internal activities improve delivery, quality, return on assets, cost effectiveness, market share and other performance indicators of the firms. With the correlation coefficient of .641, there is a clear indication that internal integration is strongly and significantly related to firm performance and the relationship is positive. Meaning, hypothesis 2 is also supported.

Lastly, the presumption that external integration has a relationship with firm performance was supported. Correlation coefficient of .754 represents a stronger relationship. Firms' collaboration with external partners, thus, suppliers and customers strongly influences its' performance and hence a strong and highly significant relationship between external integration and firm performance. Therefore, hypothesis 3 is massively supported.

\section{FINDINGS AND DISCUSSIONS}

This study was aimed at contributing to the debate on the real impact of supply chain integration on firms' performance by exploiting the supply chain integration activities of retailers in Turkey. The demographic information from the research indicated that retailers in Turkey practice supply chain integration and that majority of the firms have supply chain managers. However, the Turkish retail industry is dominated by mini markets with small number of employees. The main findings are clearly explained below.

All the hypotheses in this study were strongly supported. The relationship between internal and external integration is the strongest as the correlation coefficient was very high. Firstly, it was hypothesized that internal integration has a positive impact on external integration. The research found that the internal integration of retailers is strongly related to the 
external integration of food retailers in Turkey. This implies that food retailers maintain an integrated database and access method to facilitate information sharing, effectively shares operational information between departments, have adequate ability to share both standardized and customized information internally and provide feedback to employees on business performance. Moreover, food retailers make use of compensation, incentive and reward systems to encourage internal integration, firms extensively utilize cross-functional work teams for managing day-to-day operations, clearly define specific roles and responsibilities jointly with their partners and firms have clearly defined legal framework to guide the systematic and sequential involvement in supply chain collaboration or integration. These internal practices enlisted above can stimulate firms' willingness to maintain strategic and highly confidential information with their selected suppliers and customers and develop performance measures that extend across their supply chain relationship. Furthermore, internal integration of the firms enables firms to develop supply chain arrangements with suppliers and customers that operate under principles of shared reward and risks. Similarly, firms share technical resources with key suppliers to facilitate operations, actively pursue and share a common set of expectations with supply chain partners and are willing to enter a long-term agreement with suppliers. Essentially, it was found that the internal integration of the food retailing firms triggered their decision to relate and share strategic and vital information with their suppliers and customers. Clearly, this implies that firms should improve and continue to achieve cohesion internally since they could positively impact their ability to establish continuous extensive collaboration with supply chain partners which enable firms to develop operational flexibility and help them benchmark best practices/processes and communicate the emerging results with suppliers and customers. The strong and positive relationship between internal integration and external integration suggest that firms should develop some more collaborative systems internally as they would have a massive positive effect on their relationship with suppliers and customers.

Secondly, the research discovered a strong and positive relationship between internal integration and firm performance. This suggests that firms' internal collaboration really influences return on assets (ROA), enables firms to achieve a low cost of production, improves delivery speed and dependability, makes firm to be highly responsive to key customers, helps firms to provide desired quantities on a consistent basis and improves their ability to accommodate delivery times for specific customers. Equally, the effective collaboration of firms internally improves the ability to notify customers in advance of delivery, improves the profitability of firms through their return on investment, enables a complete satisfaction and enables firms possess an enormous portion of total sales in relation to the market it operates within (market share). The relationship between internal integration and firm performance which is simply business and operational performance indicated a strong relationship meaning, effective collaboration within firms can improve the financial and non-financial performance of the firms. The strong correlation implies that firms should continue improving their internal collaboration activities and strive to achieve high and resilient business and operational performance measures. Impliedly, a positive relationship between internal integration and firm performance means firms should be keen on collaborating effectively internally as it would have a strong positive impact on both operational and financial performance of the firms.

The third hypothesis posited that external integration has a positive influence on firm performance and this research confirmed this hypothesis by finding a positive and significant relationship between external integration and firm performance. Firms' willingness to share strategic information with selected suppliers and customers, firms' exchange of technical resources and results, firms' pursuance of principles of shared reward and risk with suppliers and customers and firms' willingness to enter long-term agreement with suppliers have a significant and strong relationship with both operational and business performance of firms. From a different point of view, firms' internal integration triggers external integration with their external partners, thus, suppliers and customers and this collaboration influences positively the business and operational performance of firms. This wholly implies that food retailers and therefore firms in general should pursue and enforce integration activities in their supply chain relationships and activities since effective and efficient supply chain collaboration would impact a positively on the business and operational performance of firms. Similarly, firms would increase operational flexibility, return on assets, reduce cost, improve delivery speed and dependability, high responsibility to customers, improve the ability to provide desirable quantities of goods and service offered for sale, accommodate delivery times and improve the ability to notify customers in advance of delivery when the products arrive. Furthermore, effective and efficient internal and external integration would exert a positive influence on the return on investment, customer satisfaction and market share. The section above presented the relationship between the variables of the study and their various implications. The research found and disclosed the relationship between all the individual variables. It was found that internal integration influences external integration which in turn influences the performance of food retail firms in Turkey. Meaning, internal and external integration all influence the business and operational performance of food retail firms. Interestingly, all the relationship proved significant, signifying that, internal integration is significantly related external integration and both are significantly related to firm performance. 


\section{CONCLUSION}

The section above presented the relationship between the variables of the study and their various implications. The research found and disclosed the relationship between all the individual variables. It was found that internal integration influences external integration which in turn influences the performance of food retail firms in Turkey. Meaning, internal and external integration all influence the business and operational performance of food retail firms. Interestingly, all the relationship proved significant, signifying that, internal integration is significantly related external integration and both are significantly related to firm performance.

This current study confirms the theory or suggestions proposed by the Stevens who suggested that firms should concentrate on internal integration and extend it to their customers and suppliers (Stevens, 1989). Furthermore, the study confirms the findings of (Stank, Crum and Arango, 1999; Stank et al., 2001; Scannell, Vickery and Droge, 2000; Prajogo and Olhager, 2012; Droge, Jayaram and Vickery, 2004; Rosenweig, Roth and Dean Jr., 2003; Stank, Daugherty and Autry, 1999; Narasimhan and Kim, 2002; Dyer, Cho and Chu, 1998; Groves and Valsamakis, 1998; Jayaram and Tan, 2010; Afshan, 2013; Marquez, Bianchi and Gupta, 2004; Vaart and Donk, 2008; Vickery et al., 2003; Lee et al., 2007; Schoenrr and Swink, 2011; Fabbe-Costes and Jahre, 2008; Wang et al., 2003; Vargas et al., 2008) who had similar findings as that of this research.

On the other hand, a contemporary research on the impact of integration on logistic performance conducted by Stank, Keller and Daugherty investigated the real impact of both internal and external integration on logistical service performance (operational performance) (Stank, Keller and Daugherty, 2001). Contrary to the findings of this research, the research found that external integration rather influences internal integration however, the research further found a positive relationship between internal integration with firm performance. Similarly, Germain and Iyer found a negative relationship between supply chain integration and financial performance but a positive relationship between integration and operational performance (Germain and lyer, 2006). Gimenez and Ventura (2000) criticized Stank, Keller and Daugherty's findings above and confirmed that internal and external integration have a positive and a strong relationship with firm performance both operational and business.

Obviously, every research is inevitably surrounded by challenges. There are a handful of challenges this study encountered. Firstly, the sampling technique reduced the number of respondents drastically. In as much as this research aims to contribute to the literature on the impact of $\mathrm{SCl}$ and performance, stratified sampling was used to select the number of respondents needed for this research. Only firms with a certain amount of capital and particular number of employees were selected since they are often considered as performing supply chain activities in their firm. This risky type of sampling means generalizing the findings to the whole food retail firms in Turkey would be diffcult and inaccurate. Secondly, this study collected data or used respondents from only two cities (Eskisehir and Istanbul) with the assumption that Istanbul and Eskisehir are one of the biggest cities in Turkey and the major food retail firms would be present in the city. This impediment restrains the research from being generalized to whole food retail firms in Turkey. Thirdly, a small number of financial performance metrics were adopted in this research even though other equally important metrics could have been used in the research. It could be concluded that the financial performance measurement in this study is inadequate. Majority of the respondents were not specifically the target of this research as this study expected supply chain managers to respond to the questions in the data collection instrument. Apparently, these respondents in the lower ranks of the business lack the technical information suitable for this research.

The gaps identified in the research presents opportunity for future researchers. Future research should expand the number of respondents and replicate the principles applied in this research. Future research should also use make use of other appropriate sampling techniques and focus the research on other equally big cities in Turkey and other cities or countries enormous retailers. This research concentrated on only food retailers without concentrating on other partners in the supply chain such as wholesalers. Future research should concentrate more on other partners such as Third Party logistics, manufacturers' suppliers and suppliers of retailers. This further re-affirms the suggestion made by Gimenez and Ventura (2005). Also since external partners such as the suppliers and customers help improve the performance of firms, information is needed to be collected from these partners to assess their viewpoint on the satisfaction of services provided by firms and benefits they derive from integrating with firms. This re-affirms the recommendations made by Gimenez \& Ventura (2005) and Stank et al. (2001). Further research is also needed to assess the drivers of supply chain integration since earlier researches have not been able to pinpoint the actual causes or drivers of integration. This gap was also identified by Flynn et al. (2010). Supply chain integration needs to be tested, clarified and researched further (Fabbe-Costes and Jahre, 2008). Due to this, several research into other areas of business and other partners is needed to solidify the real impact of supply chain integration and performance. Future research should be able to adopt more financial performance metrics and research into the real impact of supply chain integration on financial performance. This re-affirms the suggestion made by Afshan (2010). 


\section{REFERENCES}

Afshan, N. (2013). The performance outcomes of dimensions of supply chain integration: a conceptual framework. Business: Theory and Practice/Verslas: Teorija ir Praktika, 14 (4), pp.323-331.

Arbuckle, J. L. (2005). AMOS 6.0 User's Guide. Spring House, PA: Amos Development Corporation.

Chopra S. and Meindl, P. (2001). Strategy, Planning and Operation. Upper Saddle River, NJ: Prentice-Hall Inc.

Cronbach, L.J. (1951). Coefficient alpha and the internal structure of tests. Psychometrika 16, pp.297-334.

Droge, C., Jayaram, J. and Vickery, S. K. (2004). The effects of internal versus external integration practices on time-based performance and overall firm performance. Journal of Operations Management 22(6), pp.557-573.

Dyer, J. H., Cho, D. S. and Chu, W. (1998). Strategic Supplier Segmentation: The Next Best Practice in Supply Chain Management," California Management Review 40(2), pp.57-77.

El-Ansary, A.I. (1992). A strategic Perspective of Communication and Information Systems in Marketing Channels. Journal of Marketing Channels, 1(4), pp.3-16

Fabbe-Costes, N. and Jahre, M. (2008). Supply Chain Integration and Performance: A Review of The Evidence. The International Journal of Logistics Management, 19(2), pp.130-154.

Flynn, B. B., Huo, B. and Zhao, X. (2010). The Impact of Supply Chain Integration on Performance: A Contingency and Configuration Approach," Journal of Operations Management, 28 (1), pp.58-71.

Frohlich, M. T. and Westbrook, R. 2001, "Arcs of integration: an international study of supply chain strategies," Journal of Operations Management, 19(2), pp.185-200.

Germain, R. and Iyer, K. N. (2006). The interaction of internal and downstream integration and its association with performance. Journal of Business Logistics, 27(2), pp.29-52.

Gimenez, C. and Ventura, E., 2005," Logistics-production, logistics marketing and external integration: their impact on performance," International Journal of Operations \& Production Management, 25 (1), pp.20-38.

Gimenez, C., \& Ventura, E. (2003). Supply Chain Management as a Competitive Advantage in The Spanish Grocery Sector. The International Journal of Logistics Management, 14(1), pp. 77-88.

Groves, G. and Valsamakis, V. (1998). Supplier-Customer Relationships and Company Performance," The International Journal of Logistics Management, 9(2), pp. 51-64.

Hu, L. T. and Bentler, P. M. (1999). Cutoff Criteria for Fit Indexes in Covariance Structure Analysis: Conventional Criteria Versus New Alternatives. Structural Equation Modeling: A Multidisciplinary Journal, 6 (1), pp. 1-55.

Jayaram, J. and Tan, K. C. (2010). Supply Chain Integration with Third-Party Logistics Providers. International Journal of Production Economics, 125 (2), pp.262-271.

Kahn, K. B. and Mentzer, J. T. (1996). Logistics and Interdepartmental Integration. International Journal of Physical Distribution \& Logistics Management, 26 (8), pp.6-14.

Lee, H.L. (2002). Aligning Supply Chain Strategies with Product Uncertainties. California Management Review, 44 (3), pp. 105-10.

Leuschner, R., Rogers, D. S. and Charvet, F. F. (2013). A meta-analysis of supply chain integration and firm performance. Journal of Supply Chain Management, 4(9), pp.34-57.

Marquez, A. C., Bianchi, C. and Gupta, J. N. (2004). Operational and Financial Effectiveness Of E-Collaboration Tools in Supply Chain Integration. European Journal of Operational Research, 159 (2), pp. 348-363.

Narasimhan, R. and Kim, S. W. (2002). Effect of Supply Chain Integration on The Relationship Between Diversification and Performance: Evidence from Japanese And Korean Firms. Journal of operations management, 20(3), pp. 303-323.

Prajogo, D., and Olhager, J. (2012). Supply Chain Integration and Performance: The Effects Of Long-Term Relationships, Information Technology And Sharing, And Logistics Integration. International Journal of Production Economics, 135 (1), pp. $514-522$.

Rosenzweig, E. D., Roth, A. V. and Dean, J. W. (2003). The Influence of An Integration Strategy on Competitive Capabilities and Business Performance: An Exploratory Study of Consumer Products Manufacturers. Journal of Operations Management, 21(4), pp. 437-456.

Scannell, T. V., Vickery, S. K. and Droge, C. L. (2000). Upstream Supply Chain Management and Competitive Performance in The Automotive Supply Industry. Journal of Business Logistics, 21(1), p. 23.

Schoenherr, T. and Swink, M. (2012). Revisiting the Arcs of Integration: Cross-Validations And Extensions. Journal of Operations Management, 30 (1), pp. 99-115. 
Stank, T. P., Keller, S. B., and Daugherty, P. J. (2001). Supply chain collaboration and logistical service performance. Journal of Business logistics, 22(1), pp. 29-48.

Stank, T.P., Crum, M., \& Arango, M. (1999). Benefits of Interfirm Coordination in Food Industry Supply Chains. Journal of Business Logistics, 20 (2), pp. 21-41.

Stank, T.P., Daugherty, P.J. and Autry, C.W. (1999). Collaboration Planning: Supporting Automatic Replenishment Programs. International Journal of Supply Chain Management, 4(2), pp.75-85.

Stevens, G.C. (1989). Integrating the supply chain. International Journal of Physical Distribution and Materials Management, 19 (8), pp. 3-8.

Van der Vaart, T. and Van Donk, D. P. (2008). A Critical Review of Survey-Based Research in Supply Chain Integration. International Journal of Production Economics, 111 (1), pp. 42-55.

Vargas, G., Cardenas L. and Matarranz J.L. (2000). Internal and External Integration of Assembly Manufacturing Activities," International Journal of Operations and Production Management, 20(7), pp. 809-822.

Vickery, S. K., Jayaram, J., Droge, C. and Calantone, R. (2003). The Effects of An Integrative Supply Chain Strategy on Customer Service and Financial Performance: An Analysis of Direct Versus Indirect Relationships. Journal of operations management, 21 (5), pp. 523-539.

Wang, E. T., Tai, J. C. and Wei, H. L. (2006). A Virtual Integration Theory of Improved Supply-Chain Performance. Journal of Management Information Systems, 23(2), pp. 41-64.

Zailani, S. and Rajagopal, P. (2005). Supply chain integration and performance: US versus East Asian companies. Supply Chain Management: An International Journal, 10 (5), pp. 379-393.

Zhao, X., Huo, B., Flynn, B. B. and Yeung, J. H. Y. (2008). The Impact of Power and Relationship Commitment on The Integration Between Manufacturers and Customers in A Supply Chain. Journal of Operations Management, 26(3), pp. 368-388.

Zhao, X., Nie, W., Huo, B. and Yeung, J. (2006b). The Impact of Supply Chain Integration on Company Performance and Supply Chain Performance In Chin. Working Paper. The Chinese University of Hong Kong, Hong Kong. 


\section{Appendix 1: Items in the Questionnaire}

\section{Internal Integration}

INT IG 1 My firm maintains an integrated database and access method to facilitate information sharing.

INT IG 2 My firm effectively shares operational information between departments.

INT IG 3 My firm has adequate ability to share both standardized and customized information internally.

INT IG 4 My firm provides objective feedback to employees regarding integrated on business and logistics performance

INT IG 5 My firm's compensation, incentive and reward systems encourage integration.

INT IG 6 My firm extensively utilizes cross-functional work teams for managing day-to- day operations.

INT IG 7 My firm clearly defines specific roles and responsibilities jointly with our supply chain partners.

INT IG 8 My firm has clearly defined a legal framework to guide involvement in supply chain collaboration

\section{External Integration}

EXT IG 1 My firm is willing to share strategic information with selected suppliers and/or customers.

EXT IG 2 My firm has developed performance measures that extend across supply chain relationships.

EXT IG 3 My firm experiences improved performance by integrating operations with supply chain partners.

EXT IG 4 My firm has increased operational flexibility through supply chain collaboration

EXT IG 5 My firm benchmarks best practices/processes and shares results with suppliers.

EXT IG 6 My firm has supply chain arrangements with suppliers and customers that operate under principles of shared rewards and risks.

EXT IG 7 My firm shares technical resources with key suppliers to facilitate operations

EXT IG 8 My firm actively pursues and shares a common set of expectations with supply chain partners.

EXT IG 9 My firm is willing to enter long-term agreements with suppliers.

Firm's Performance

PERF 1 (ROA) The ratio of income before interest expense divided by average total assets.

PERF 2 The ability to achieve the lowest total cost of through efficient operations, technology and/or scale economies.

PERF 3 The ability to reduce the time between order receipt and customer delivery to as close to zero as possible.

PERF 4 The ability to meet quoted or anticipated delivery dates and quantities on a consistent basis.

PERF 5 The ability to respond to the needs and wants to key customers.

PERF 6 The ability to provide desired quantities on a consistent basis.

PERF 7 The ability to accommodate delivery times for specific customers.

PERF 8 The ability to modify customers in advance of delivery when the product will arrive.

PERF 9 (ROI) A profitability measure that evaluates the performance of a business by dividing net profit by net worth.

PERF 10 The product supplied matches customer's specification and requirement.

PERF 11 The firm's portion of total sales in relation to the market it operates within. 